\title{
The Crystal and Molecular Structure of Semisquaric Acid (3-Hydroxy-3-cyclobutene-1,2-dione)
}

\author{
Dag Semmingsen ${ }^{\mathrm{a}, \star}$ and Per Groth ${ }^{\mathrm{b}}$ \\ aInstitutt for Matematikk og Naturvitenskap, Høgskolesenteret i Rogaland, N-4000 Stavanger and

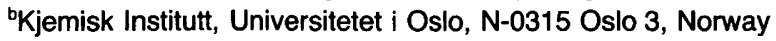

\begin{abstract}
Semmingsen, D. and Groth, P., 1988. The Crystal and Molecular Structure of Semisquaric Acid (3-Hydroxy-3-cyclobutene-1,2-dione). - Acta Chem. Scand., Ser. B 42: 1-6.

The crystal and molecular structure of semisquaric acid (3-hydroxy-3-cyclobutene-1,2-dione) has been determined by X-ray methods at $133(3) \mathrm{K}$, from 1678 independent reflections. The crystals are monoclinic, $P 2_{1} / n$, with cell dimensions $a=10.328, b=11.139, c=13.796 \AA, \beta=94.75^{\circ}$. The structure was refined to a conventional $R$-value of 0.038 . There are four independent molecules in the asymmetric unit, and one of the molecules adopts a slightly different conformation from the others. There are only minor differences between corresponding bonds in the different molecules; these are considered insignificant. However, some $\mathrm{C}-\mathrm{C}-\mathrm{O}$ bond angles differ in the two conformers. The origin of these differences is discussed.
\end{abstract}

Semisquaric acid (3-hydroxy-3-cyclobutene1,2-dione) has a quite unusual and simple structure for a biologically active compound. ${ }^{1}$ The mold Fusarium moniliforme, isolated from maize seed, was found to produce a water soluble mycotoxin; it was given the trivial name moniliformin and was found to be identical with the sodium salt of semisquaric acid. ${ }^{1}$ The corresponding mycotoxin from Gibberella fujikuroi was found by Xray analysis to be the potassium salt. ${ }^{2}$ The compounds have growth regulating effects on plants such as maize and tobacco, ${ }^{1}$ and even on wheat and barley. ${ }^{3}$ Prior to these discoveries, semisquaric acid had been prepared in the laboratory, ${ }^{4}$ and several synthetic routes are now available. ${ }^{5}$ The interest in semisquaric acid from a structural point of view stems from its extremely high acidity $\left(\mathrm{p} K_{\mathrm{A}}=0.0\right)^{6}$ and the associated ability to form strong hydrogen bonds. We have previously investigated the structures of squaric ${ }^{7}$ and deltic acids, ${ }^{8}$ and we report here the results of a determination of the structure of semisquaric acid.

\section{Experimental}

A sample of the compound provided by Dr. D. Belluš of the Ciba-Geigy laboratory in Basel was recrystallized from butanol. The crystal was mounted on the Nicolet $P 3 / F$ diffractometer at the Chemistry Department, UiO, and data were collected at 133(3) K with an Enraf-Nonius liquid $\mathrm{N}_{2}$ gas-flow cooling device, using graphite-monochromated MoKo radiation $(\lambda=0.71069 \AA)$, and scanning in the $\omega$-mode. Data were collected out to $2 \theta=55.0^{\circ}$, at a variable scan speed dependent on intensity; background counts were measured at each end of the scan. Cell parameters were determined from the orientation matrix based on the least-squares fit of the centering of 25 individual reflections in the counter aperture. Standard deviations in the measured intensities were calculated as $\sigma(I)=\left[C_{\mathrm{A}}+\left(0.02 \cdot C_{\mathrm{B}}\right)^{2}\right]^{1 / 2}$, where $C_{\mathrm{A}}$ is the total count and $C_{\mathrm{B}}$ is the total count minus the background count. The usual corrections were made for Lorentz and polarization effects, but not for extinction or absorption.

\footnotetext{
*'To whom correspondence should be addressed.
} 


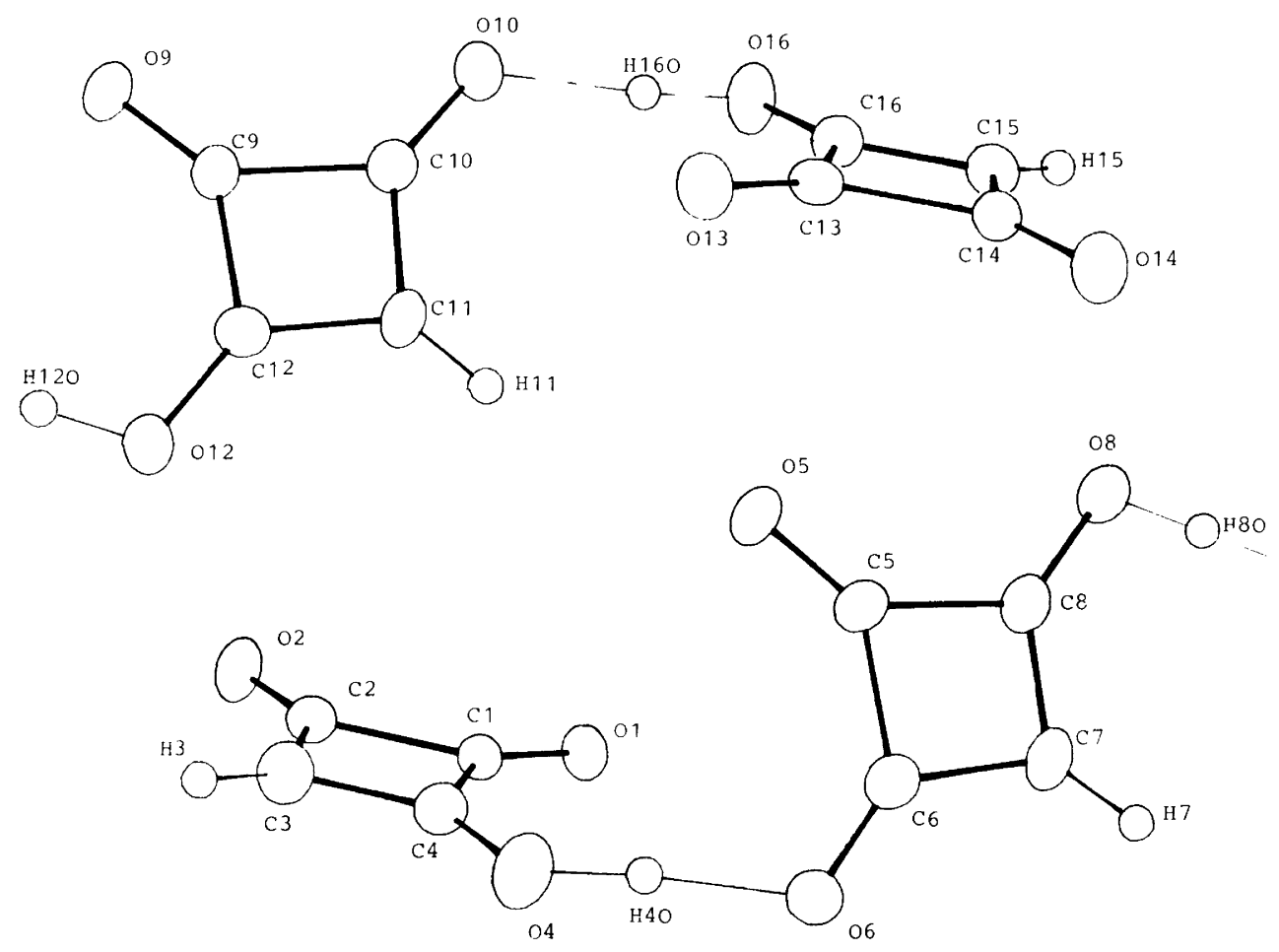

Fig. 1. The four different molecules in the asymmetric unit and their atom numbering scheme. Lower left: molecule a; lower right: b; upper left: c; upper right: $\mathbf{d}$.
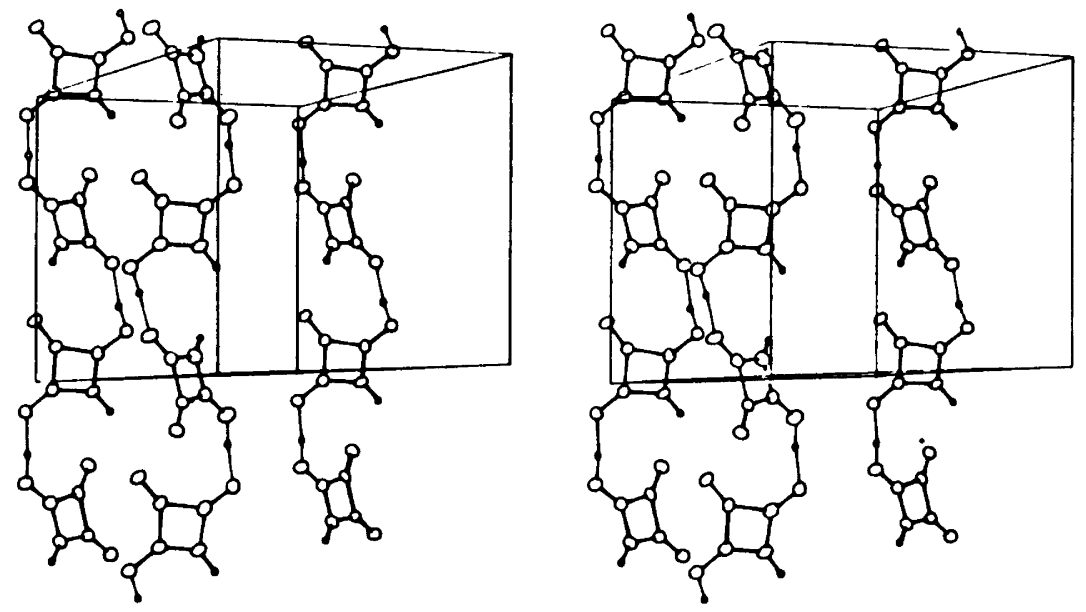

Fig. 2. Strings of hydrogen-bonded molecules along the a-axis. The $b$-axis is approximately horizontal. 2 


\section{Crystal data}

Semisquaric acid (3-hydroxy-3-cyclobutene1,2-dione), $\mathrm{C}_{4} \mathrm{H}_{2} \mathrm{O}_{3}$; monoclinic, $P 2_{1} / n ; a=$ $10.328(2), b=11.139(2), c=13.796(2) \AA, \beta=$ $94.75(1)^{\circ}, D_{\mathrm{m}}=1.6 \mathrm{~g} \mathrm{~cm}^{-3}, D_{\mathrm{x}}=1.65 \mathrm{~g} \mathrm{~cm}^{-3}, \mu$ $=1.37 \mathrm{~cm}^{-1}$.

\section{Structure determination}

The structure was solved by the direct methods programme assembly MITHRIL. ${ }^{9}$ The structure was refined by the full-matrix least-squares technique, the hydrogens being located in a difference Fourier map and included in the refinements with isotropic temperature factors. All heavy atoms were given anisotropic temperature factors. In the final cycle of refinements the following agreement factors were obtained: $R=$ $0.038, R_{\mathrm{w}}=0.037$ and $S=1.65$ for a total of 1678 reflections and 285 parameters. The quantity minimized was $\Sigma w(\Delta F)^{2}$, where $w$ is the inverse variance of the observed structure factor. The standard deviations given for the derived quantities are those derived from the variance-covariance matrix. A structure factor list may be obtained from the authors on request.

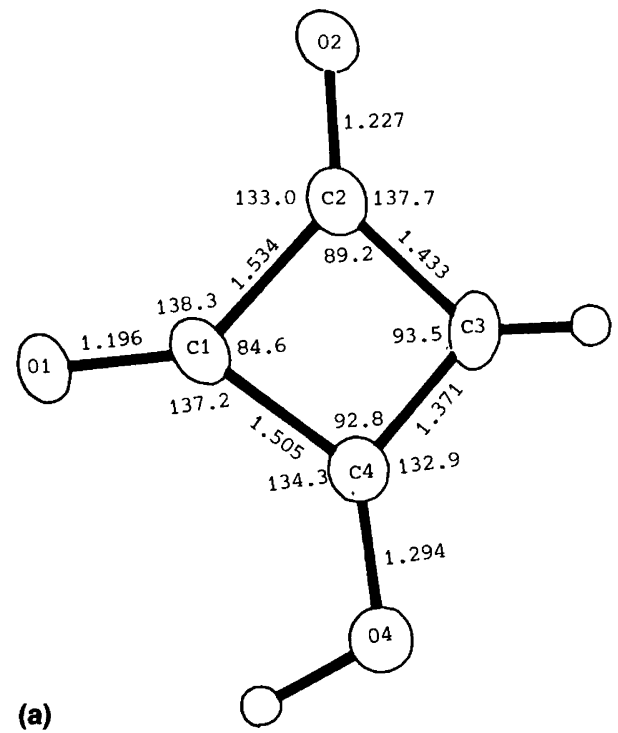

\section{Results and discussion}

The structural solution gave four independent molecules in the asymmetric unit. Their labelling and the atom numbering scheme are shown in Fig. 1, and the arrangement of the molecules in the crystal in Fig. 2. Final coordinates for the heavy atoms are listed in Table 1, while those for the hydrogens are given in Table 2. Bond distances and angles for individual molecules are given in Table 3 . Average bond lengths and angles for the molecules a, $\mathbf{c}$ and $\mathbf{d}$ are given in Fig. $3 \mathrm{a}$ while the bond lengths and angles for molecule b are given in Fig. 3b. Standard deviations in average quantities are calculated from $\sigma^{-2}=n^{-1}$. $\Sigma_{\mathrm{i}} \sigma_{\mathrm{i}}^{-2}$ (obs).

The molecules are joined into two independent chains by hydrogen bonds running along [100]. Hydrogen bond donation and acceptance in the molecules invariably occur between the two groups arranged oppositely along a diagonal of the molecule. The four different hydrogen bonds are all clearly asymmetric and relatively strong. Their lengths range from 2.521(4) $\AA$ to 2.579(4) $\AA$, with an average value of $2.543(3) \AA$ comparable to those found in squaric acid [2.549(1) $\AA]]^{7}$ They are definitely shorter than $2.64 \AA$, the stan-

(b)

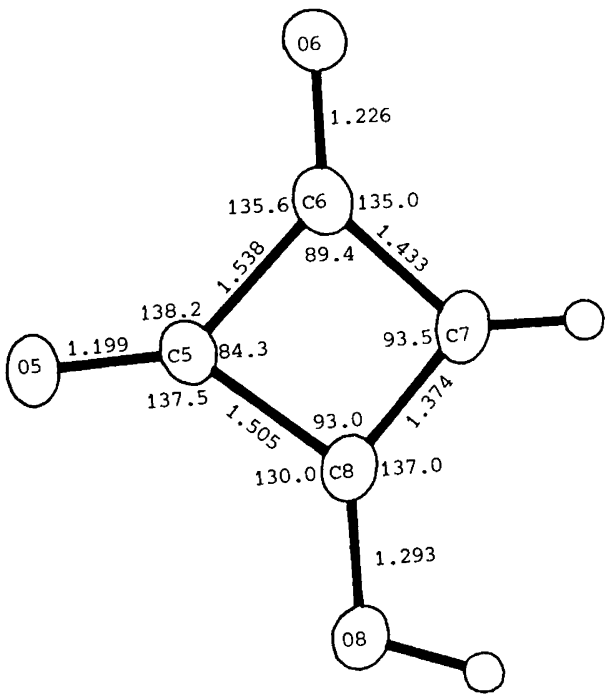

Fig. 3. (a) Average bond lengths $(\AA)$ and angles ( $\left.{ }^{\circ}\right)$ for molecules a, c and d. E.s.d.'s are 0.003 and $0.002 \AA$ in $\mathrm{C}-\mathrm{C}$ and $\mathrm{C}-\mathrm{O}$ bonds, respectively, and $0.2^{\circ}$ in angles. (b) Bond lengths $(\AA)$ and angles $\left(^{\circ}\right)$ in molecule $b$. 
Table 1. Final fractional coordinates (with e.s.d.'s) and equivalent temperature factors for non-hydrogen atoms.

\begin{tabular}{|c|c|c|c|c|}
\hline Atom & $x$ & $y$ & $z$ & $U_{\mathrm{eq}}{ }^{a}$ \\
\hline 01 & $.1765(2)$ & $.1360(2)$ & $.5977(1)$ & .025 \\
\hline $\mathrm{O} 2$ & $-.1338(2)$ & $.0817(2)$ & $.5390(2)$ & .029 \\
\hline $\mathrm{O} 4$ & $.1371(2)$ & $.3921(2)$ & $.4792(2)$ & .030 \\
\hline O5 & $.3324(2)$ & $.1304(2)$ & $.4021(1)$ & .025 \\
\hline O6 & $.3732(2)$ & $.3729(2)$ & $.5398(2)$ & .032 \\
\hline O8 & $.6360(2)$ & $.0698(2)$ & $.4516(2)$ & .027 \\
\hline 09 & $-.2069(2)$ & $-.0899(2)$ & $.1603(1)$ & .026 \\
\hline 010 & $.1018(2)$ & $-.1456(2)$ & $.2009(2)$ & .029 \\
\hline 012 & $-.1597(2)$ & $.1626(2)$ & $.2802(2)$ & .028 \\
\hline 013 & $.2945(2)$ & $.0965(2)$ & $.1647(1)$ & .026 \\
\hline 014 & $.6027(2)$ & $.1480(2)$ & $.2168(2)$ & .026 \\
\hline 016 & $.3390(2)$ & $-.1738(2)$ & $.2577(2)$ & .028 \\
\hline C1 & $.0874(3)$ & $.1851(3)$ & $.5534(2)$ & .022 \\
\hline $\mathrm{C} 2$ & $-.0584(3)$ & $.1634(3)$ & $.5247(2)$ & .023 \\
\hline C3 & $-.0642(3)$ & $.2775(3)$ & $.4765(2)$ & .027 \\
\hline C4 & $.0646(3)$ & $.3015(3)$ & $.4985(2)$ & .023 \\
\hline C5 & $.4200(3)$ & $.1786(3)$ & $.4496(2)$ & .021 \\
\hline C6 & $.4415(3)$ & $.2906(3)$ & $.5141(2)$ & .024 \\
\hline $\mathrm{C7}$ & $.5757(3)$ & $.2587(3)$ & $.5319(2)$ & .025 \\
\hline $\mathrm{C} 8$ & $.5623(3)$ & $.1565(3)$ & $.4762(2)$ & .022 \\
\hline $\mathrm{Cg}$ & $-.1150(3)$ & $-.0403(3)$ & $.2010(2)$ & .020 \\
\hline $\mathrm{C} 10$ & $.0308(3)$ & $-.0629(3)$ & $.2219(2)$ & .021 \\
\hline $\mathrm{C} 11$ & $.0419(3)$ & $.0488(3)$ & $.2733(2)$ & .022 \\
\hline C12 & $-.0879(3)$ & $.0740(3)$ & $.2566(2)$ & .021 \\
\hline C13 & $.3856(3)$ & $.0417(3)$ & $.2012(2)$ & .021 \\
\hline C14 & $.5309(3)$ & $.0614(3)$ & $.2266(2)$ & .020 \\
\hline C15 & $.5409(3)$ & $-.0583(3)$ & $.2644(2)$ & .022 \\
\hline C16 & $.4103(3)$ & $-.0810(3)$ & $.2442(2)$ & .023 \\
\hline
\end{tabular}

${ }^{a} U_{\text {eq }}=\left(U_{11}+U_{22}+U_{33}\right) / 3$.

dard value for the hydrogen bonds of carboxylic acids in the solid state. The fragment $\mathrm{HO}-$ $\mathrm{C}=\mathrm{CH}-\mathrm{C}=\mathrm{O}$ may be regarded as the next higher vinylogue of the carboxylic acid fragment, $\mathrm{HO}-\mathrm{C}=\mathrm{O}$, and it is generally found that the former forms stronger hydrogen bonds. The hydrogen bonds in semisquaric acid are slightly nonlinear, the average $\mathrm{O}-\mathrm{H} \cdots \mathrm{O}$ angle being 172.5 $(8)^{\circ}$.

One of the molecules (b) adopts a conformation different from that of the other three, since the $\mathrm{O}-\mathrm{H}$ vector in this molecule points roughly in the same direction as that of the $\mathrm{C}-\mathrm{H}$ bond. In the other three molecules the $\mathrm{O}-\mathrm{H}$ bond vector points along the $\mathrm{C}=\mathrm{O}$ vector (see Fig. 1). Except for some deviations in the angles for the hydroxy and carbonyl groups engaged in hydrogen bond- ing (see below), no other differences in the structural parameters are found for the two conformers. Since there are few significant discrepancies between corresponding bonds in any of the four independent molecules, the discussion will mainly concern the average bond lengths (Fig. 3). Semisquaric acid is obtained by replacing one of the hydroxy groups in squaric acid with hydrogen, and the latter will therefore serve as the main reference point for the discussion.

The conjugation in the molecules seems to be concentrated in the alternating bond system linking the hydrogen bond donor and acceptor groups; thus, the formal $\mathrm{C}=\mathrm{C}$ double bond is reduced in length from $1.408(1) \AA$ in squaric acid to $1.372(3) \AA$ in semisquaric acid, while the vicinal formal $\mathrm{C}-\mathrm{C}$ single bond is reduced by $0.025 \AA$ to $1.433(2) \AA$. The lengths of the $\mathrm{C}-\mathrm{O}$ and $\mathrm{C}=\mathrm{O}$ bonds engaged in hydrogen bonds are virtually identical to those of corresponding bonds in squaric acid. The remaining $\mathrm{C}=\mathrm{O}$ bond and the two adjacent intra-ring bonds differ substantially in length from those in squaric acid; the former is short $[1.197(2) \AA]$ and is similar in length to that in phenylcyclobutenedione $[1.205(10) \AA] .{ }^{10}$ The $\mathrm{C}-\mathrm{C}$ single bond length in the diketone moiety $[1.535(3) \AA]$ is also similar to that in phenylcyclobutenedione [1.543(6) $\AA]$. The final intraring bond is somewhat longer [1.505(4) $\AA]$ than observed for corresponding bonds in other cyclobutenediones $(1.46-1.49 \AA) .{ }^{11}$ There are also differences in the intra-ring bond angles in the two molecules: In particular, the angle at the carbon carrying the vinylic proton is enlarged $1.7^{\circ}$ relative to that in squaric acid, while the angle at the non-bonded $\mathrm{C}=\mathrm{O}$ group is reduced from $88.2(1)$ to $84.4(3)^{\circ}$ in semisquaric acid.

Table 2. Final fractional coordinates and isotropic temperature factors (with e.s.d.'s) for hydrogen atoms.

\begin{tabular}{lrlll}
\hline Atom & $x$ & $y$ & $z$ & $U$ \\
\hline $\mathrm{H} 3$ & $-.127(3)$ & $.318(2)$ & $.443(2)$ & $.02(1)$ \\
$\mathrm{H} 7$ & $.647(4)$ & $.293(3)$ & $.566(3)$ & $.07(1)$ \\
$\mathrm{H} 11$ & $.110(3)$ & $.091(3)$ & $.305(2)$ & $.01(1)$ \\
$\mathrm{H} 15$ & $.603(4)$ & $-.103(3)$ & $.292(3)$ & $.03(1)$ \\
$\mathrm{H} 40$ & $.234(5)$ & $.377(3)$ & $.505(3)$ & $.09(1)$ \\
$\mathrm{H} 8 \mathrm{O}$ & $.723(4)$ & $.081(3)$ & $.483(3)$ & $.07(1)$ \\
$\mathrm{H} 12 \mathrm{O}$ & $-.247(4)$ & $.150(4)$ & $.253(3)$ & $.07(1)$ \\
$\mathrm{H} 16 \mathrm{O}$ & $.244(4)$ & $-.156(4)$ & $.235(3)$ & $.09(1)$ \\
\hline
\end{tabular}


Table 3. Bond distances $(\AA)$ and angles $\left(^{\circ}\right)$ with e.s.d.'s. The symmetry operator is: ': $x-1, y, z$.

\begin{tabular}{|c|c|c|c|}
\hline \multicolumn{2}{|l|}{ Distance } & \multicolumn{2}{|l|}{ Distance } \\
\hline $\mathrm{O} 1-\mathrm{C} 1$ & $1.194(4)$ & $\mathrm{O} 2-\mathrm{C} 2$ & $1.225(5)$ \\
\hline $\mathrm{O} 2 \cdot \cdot \mathrm{H} 8 \mathrm{O}$ & $1.61(5)$ & $\mathrm{O} 4-\mathrm{C} 4$ & $1.297(4)$ \\
\hline $\mathrm{O} 4-\mathrm{H} 4 \mathrm{O}$ & $1.05(5)$ & O5-C5 & $1.199(4)$ \\
\hline O6-C6 & $1.226(4)$ & $\mathrm{O} 6 \cdot \cdot \mathrm{H} 4 \mathrm{O}$ & $1.48(5)$ \\
\hline $\mathrm{O} 8-\mathrm{C} 8$ & $1.293(4)$ & $\mathrm{O} 8-\mathrm{H} 8 \mathrm{O}$ & $0.97(5)$ \\
\hline O9-C9 & $1.197(4)$ & O10-C10 & $1.226(4)$ \\
\hline $\mathrm{O} 10 \cdot \cdot \mathrm{H} 16 \mathrm{O}$ & $1.51(5)$ & $\mathrm{O} 12-\mathrm{C} 12$ & $1.293(4)$ \\
\hline $\mathrm{O} 12-\mathrm{H} 12 \mathrm{O}$ & $0.96(5)$ & O13-C13 & $1.197(4)$ \\
\hline O14-C14 & $1.231(4)$ & $\mathrm{O} 14 \cdot \cdot \mathrm{H} 12 \mathrm{O}$ & $1.59(5)$ \\
\hline $016-\mathrm{C}_{16}$ & $1.291(4)$ & $\mathrm{O} 16-\mathrm{H} 16 \mathrm{O}$ & $1.02(5)$ \\
\hline $\mathrm{C} 1-\mathrm{C} 2$ & $1.544(5)$ & $\mathrm{C} 1-\mathrm{C} 4$ & $1.510(5)$ \\
\hline $\mathrm{C} 2-\mathrm{C} 3$ & $1.433(5)$ & C3-C4 & $1.366(5)$ \\
\hline $\mathrm{C} 3-\mathrm{H} 3$ & $0.89(3)$ & C5-C6 & $1.538(5)$ \\
\hline C5-C8 & $1.505(5)$ & C6-C7 & $1.433(5)$ \\
\hline C7-C8 & $1.374(5)$ & $\mathrm{C} 7-\mathrm{H} 7$ & $0.93(4)$ \\
\hline C9-C10 & $1.531(5)$ & $\mathrm{C} 9-\mathrm{C} 12$ & $1.501(5)$ \\
\hline $\mathrm{C}_{10}-\mathrm{C}_{11}$ & $1.433(5)$ & $\mathrm{C}_{11-C} 12$ & $1.370(5)$ \\
\hline $\mathrm{C} 11-\mathrm{H} 11$ & $0.93(4)$ & $\mathrm{C}_{13}-\mathrm{C}_{14}$ & $1.528(5)$ \\
\hline C13-C16 & $1.504(5)$ & C14-C15 & $1.432(5)$ \\
\hline C15-C16 & $1.378(5)$ & $\mathrm{C} 15-\mathrm{H} 15$ & $0.88(4)$ \\
\hline $\mathrm{O} 2 \cdot \mathrm{O}^{\prime}$ & $2.579(4)$ & 04.06 & $2.521(4)$ \\
\hline $010 \cdot 016$ & $2.529(4)$ & $012 \cdot 014^{\prime}$ & $2.541(4)$ \\
\hline Angle & & Angle & \\
\hline $\mathrm{O} 1-\mathrm{C} 1-\mathrm{C} 2$ & $138.8(3)$ & $\mathrm{O} 1-\mathrm{C} 1-\mathrm{C} 4$ & $137.0(3)$ \\
\hline $\mathrm{C} 2-\mathrm{C} 1-\mathrm{C} 4$ & $84.1(3)$ & $\mathrm{O} 2-\mathrm{C} 2-\mathrm{C} 1$ & $134.0(3)$ \\
\hline $\mathrm{O} 2-\mathrm{C} 2-\mathrm{C} 3$ & $137.0(4)$ & $\mathrm{C} 1-\mathrm{C} 2-\mathrm{C} 3$ & $89.0(3)$ \\
\hline $\mathrm{C} 2-\mathrm{C} 3-\mathrm{C} 4$ & $93.9(3)$ & $\mathrm{O} 4-\mathrm{C} 4-\mathrm{C} 1$ & $134.6(3)$ \\
\hline $\mathrm{O} 4-\mathrm{C} 4-\mathrm{C} 3$ & $132.5(3)$ & $\mathrm{C}-\mathrm{C} 4-\mathrm{C} 3$ & $93.0(3)$ \\
\hline $\mathrm{O} 5-\mathrm{C} 5-\mathrm{C} 6$ & $138.2(3)$ & $\mathrm{O} 5-\mathrm{C} 5-\mathrm{C} 8$ & $137.5(3)$ \\
\hline C6-C5-C8 & $84.3(3)$ & $\mathrm{O} 6-\mathrm{C} 6-\mathrm{C} 5$ & $135.6(3)$ \\
\hline $\mathrm{O} 6-\mathrm{C} 6-\mathrm{C} 7$ & $135.0(3)$ & $\mathrm{C} 5-\mathrm{C} 6-\mathrm{C} 7$ & $89.4(3)$ \\
\hline C6-C7-C8 & $93.3(3)$ & $\mathrm{O} 8-\mathrm{C} 8-\mathrm{C} 5$ & $130.0(3)$ \\
\hline $\mathrm{O} 8-\mathrm{C} 8-\mathrm{C} 7$ & $137.0(3)$ & $\mathrm{C} 5-\mathrm{C} 8-\mathrm{C7}$ & 93.0(3) \\
\hline $\mathrm{O}-\mathrm{Cg}-\mathrm{C} 10$ & $137.9(3)$ & $\mathrm{O}-\mathrm{C}-\mathrm{C} 12$ & $137.6(3)$ \\
\hline $\mathrm{C} 10-\mathrm{C} 9-\mathrm{C} 12$ & $84.5(3)$ & $\mathrm{O} 10-\mathrm{C} 10-\mathrm{C} 9$ & $132.6(3)$ \\
\hline $\mathrm{O} 10-\mathrm{C} 10-\mathrm{C} 11$ & $138.1(4)$ & $\mathrm{C} 9-\mathrm{C}_{10}-\mathrm{C}_{11}$ & $89.3(3)$ \\
\hline $\mathrm{C}_{10}-\mathrm{C}_{11}-\mathrm{C}_{12}$ & $93.3(3)$ & $\mathrm{O} 12-\mathrm{C} 12-\mathrm{C} 9$ & $133.6(3)$ \\
\hline O12-C12-C11 & $133.4(3)$ & $\mathrm{C}-\mathrm{C} 12-\mathrm{C} 11$ & $93.0(3)$ \\
\hline O13-C13-C14 & $138.3(3)$ & O13-C13-C16 & $136.9(4)$ \\
\hline C14-C13-C16 & $84.8(3)$ & O14-C14-C13 & $132.5(3)$ \\
\hline O14-C14-C15 & 138.1(4) & C13-C14-C15 & $89.4(3)$ \\
\hline C14-C15-C16 & 93.3(3) & $\mathrm{O} 16-\mathrm{C}_{16}-\mathrm{C}_{13}$ & $134.8(3)$ \\
\hline O16-C16-C15 & $132.7(3)$ & $\mathrm{C}_{13}-\mathrm{C}_{16}-\mathrm{C}_{15}$ & $92.5(3)$ \\
\hline $\mathrm{O} 4-\mathrm{H} 4 \mathrm{O} \cdot \mathrm{O} 06$ & $172.3(3)$ & $\mathrm{O} 2 \cdot \cdot \mathrm{H} 8 \mathrm{O}^{\prime}-\mathrm{O}^{\prime}$ & $172.8(3)$ \\
\hline O12-H12O..014' & $171.6(3)$ & $010 \cdot \cdot \mathrm{H} 160-016$ & $173.4(3)$ \\
\hline
\end{tabular}

As seen from Fig. 3, the $\mathrm{C}=\mathrm{C}-\mathrm{O}$ bond angles cis to the hydrogen bond donor and acceptor are enlarged compared to those trans. Similar observations have been made for a number of hydro- gen-bonded systems, and have been explained by intramolecular repulsions between the hydrogenbonded proton and the carbon atom carrying the hydroxy group. ${ }^{12}$ However, in semisquaric acid, 
Table 4. $\mathrm{C}-\mathrm{H} \cdots \mathrm{O}$ interactions with $r(\mathrm{H} \cdots \mathrm{O})$ less than $2.70 \AA$.

\begin{tabular}{llll}
\hline $\mathrm{C}-\mathrm{H} \cdots \mathrm{O}$ & $r(\mathrm{C} \cdots \mathrm{O}) / \AA$ & $r(\mathrm{H} \cdots \mathrm{O}) / \AA$ & $\angle \mathrm{C}-\mathrm{H} \cdots \mathrm{O} /$ \\
\hline $\mathrm{C} 3-\mathrm{H} 3 \cdots \mathrm{O} 9$ & 3.254 & 2.37 & 174.2 \\
$\mathrm{C} 7-\mathrm{H} 7 \cdots \mathrm{O} 13$ & 3.222 & 2.31 & 168.3 \\
$\mathrm{C} 11-\mathrm{H} 11 \cdots \mathrm{O} 5$ & 3.478 & 2.59 & 159.2 \\
$\mathrm{C} 15-\mathrm{H} 15 \cdots \mathrm{O} 1$ & 3.460 & 2.66 & 153.2 \\
\hline
\end{tabular}

and in squaric acid and its acid salts, ${ }^{13,14}$ similar, albeit smaller, distortions also affect the acceptor groups, presumably because the hydrogen bonds in these materials are short. In the two conformers of semisquaric acid, these deviations have different magnitudes, and we believe that they represent a compromise between the 1-3 repulsion mentioned above and a tendency to adopt more favourable bond angles for the conjugated $\mathrm{O}=\mathrm{C}-\mathrm{C}=\mathrm{C}-\mathrm{OH}$ arrangement. According to VSEPR theory, multiple bonds repel single bonds more strongly than single bonds repel other single bonds; hence, a bond-angle reduction of about $2-3^{\circ}$ between the singly bonded substituents, and a corresponding enlargement of the other angles, is commonly found. Judging from the values of the bond lengths in semisquaric acid there is considerable contribution also from the resonance form $\mathrm{O}-\mathrm{C}=\mathrm{C}-\mathrm{C}=\mathrm{OH}^{+}$, and thus particularly the endocyclic angle at $\mathrm{C} 3$ and the exocyclic at $\mathrm{C} 2$ and $\mathrm{C} 4$ within the conjugated bond system should enlarge. The effects of electron pair repulsion and non-bonded repulsion reinforce each other at $\mathrm{C} 2$ in $\mathbf{a}$ and at $\mathrm{C} 8$ in $\mathbf{b}$, and oppose each other at $\mathrm{C} 4$ in a and at $\mathrm{C} 6$ in b (see Fig. 3).

The molecules a, b and $\mathbf{c}$ are planar within estimated standard deviations. In molecule d, the diketone moiety is twisted, with $0130.017 \AA$ below and $0140.017 \AA$ above the mean molecular plane. However, the conjugated bond system between $\mathrm{O} 14$ and $\mathrm{O} 16$ is essentially planar. Even in molecules $\mathbf{a}, \mathbf{b}$ and $\mathbf{c}$, the atoms in this fragment show smaller deviations from planarity than the other atoms.

In addition to the $\mathrm{O}-\mathrm{H} \cdots \mathrm{O}$ hydrogen bonds, there are well-defined $\mathrm{C}\left(s p^{2}\right)-\mathrm{H} \cdots \mathrm{O}$ interactions in the crystal, ${ }^{15,16}$ since all four hydrogen atoms and all four otherwise unbonded $\mathrm{C}=\mathrm{O}$ groups participate. The distances and angles involved are given in Table 4.

\section{References}

1. Cole, R. J., Kirksey, J. W., Cutler, H. G., Doupnik, B. L. and Peckham, J. C. Science 179 (1973) 1324.

2. Springer, J. P., Clardy, J., Cole, R. J., Kirksey, J. W., Hill, R. K., Carlson, R. M. and Isidor, J. L. J. Am. Chem. Soc. 96 (1974) 2267.

3. Scharf, H.-D. and Frauenrath, H. In: West, R., Ed., Oxocarbons, Academic Press, New York 1980 , p. 101.

4. Hoffman, R.W., Bressel, U., Gehlhaus, J. and Häuser, H. Chem. Ber. 104 (1971) 873.

5. Belluš, D., Fischer, H., Greuter, H. and Martin, P. Helv. Chim. Acta. 61 (1978) 1784.

6. Belluš, D. In: West, R., Ed., Oxocarbons, Academic Press, New York 1980, p. 169.

7. Semmingsen, D. Acta Chem Scand. 27 (1973) 3961.

8. Semmingsen, D. and Groth, P. J. Am. Chem. Soc. 109 (1987) 7238.

9. Gilmore, C. J. J. Appl. Crystallogr. 17 (1984) 42.

10. Wong, C. H., Marsh, R.E. and Schomaker, V. Acta Crystallogr. 17 (1964) 131.

11. Ref. 7 and references therein.

12. Hirshfeld, F. L. Israel J. Chem. 2 (1964) 87.

13. Semmingsen, D. Acta Chem. Scand., Ser. A30 (1976) 808.

14. Nordenson, S. and Semmingsen, D. To be published.

15. Taylor, R. and Kennard, O. J. Am. Chem. Soc. 104 (1982) 5063.

16. Berkovitch-Yellin, Z. and Leiserovitz, L. Acta Crystallogr., Sect. B 40 (1984) 159.

Received June 29, 1987. 